\title{
Pemanfaatan Kotoran Ternak Sebagai Sumber Energi Alternatif di Kelompok Ternak Sapi Potong Sido Makmur Umbulsari Jember
}

\author{
Nurkholis $^{1 *}$, Suluh Nusantoro ${ }^{2}$, Aan Awaludin ${ }^{3}$, M. Adhyatma ${ }^{4}$, Bagus Djuni ${ }^{5}$ \\ 1,2,3,4 Jurusan Peternakan, Politeknik Negeri Jember \\ 1nur78.nk@gmail.com, ${ }^{2}$ suluh.nusantoro@gmail.com, ${ }^{3}$ aanawaludin@gmail.com, \\ ${ }^{4} \mathrm{~m} \_$adhyatma@polije.ac.id, ${ }^{5}$ bagusdjuni257@gmail.com
}

\begin{abstract}
The sustainability of the livestock business does not only depend on the success of the maintenance system which aims at increasing productivity, but also on the ability to process the resulting livestock waste. Livestock waste is the main source of quality degradation for the environment, this occurs due to the presence of ammonia and methane gas which is formed from the decomposition of organic matter. Ammonia along with other gases can cause acid rain, while methane gas causes a greenhouse effect. This community service partner is a farmer who is part of the "Sido Makmur" beef cattle group in Umbulrejo village, Umbulsari sub-district, Jember district. The purpose of this community service activity is to transfer knowledge and technology regarding livestock waste processing to be used as biogas. The selection of waste treatment topics is based on a situation analysis of the "Sido Makmur" livestock group. The results of the situation analysis show that generally livestock manure is not processed and is left around the stables and there are some group members who have difficulty buying LPG fuel because it is considered quite expensive. The implementation of the service consists of several activitie, the first was outreach activities, demonstrations / practices and assistance of community service activities. The results of the community service survey which have shown that the application of technology in the processing or utilization of livestock manure into a useful material that even has economic value will support the creation of an environmentally friendly livestock system or zerro waste system, besides that it will also improve the welfare of breeders through minimizing the cost of purchasing fuel.
\end{abstract}

Keywords: Manure, alternative energy, ammonia, biogas and the greenhouse effect

\section{Abstrak}

Keberlanjutan usaha peternakan tidak hanya tergantung pada keberhasilan pada sistem pemeliharaan yang bertujuan pada peningkatan produktivitas, akan tetapi terletak juga pada kemampuan dalam mengolah limbah ternak yang dihasilkan. Limbah ternak merupakan sumber utama penurunan kualitas bagi lingkungan, ini terjadi karena adanya gas amonia dan metan yang terbentuk dari proses dekomposisi bahan organik. Amonia bersama gas lain dapat menimbulkan hujan asam, sedangkan gas metan mengakibatkan efek rumah kaca. Mitra program Pengabdian Kepada Masyarakat ini adalah peternak yang terwadahi dalam kelompok ternak sapi potong "Sido Makmur” yang berada di desa Umbulrejo, kecamatan Umbulsari, kabupaten Jember. Tujuan kegiatan pengabdian kepada masyarakat ini adalah mentransfer pengetahuan dan teknologi mengenai pengolahan limbah ternak untuk digunakan sebagai biogas. Pemilihan topik pengolahan limbah didasarkan pada analisis situasi pada kelompok ternak "Sido Makmur". Hasil analisis situasi, umumnya kotoran ternak tidak diolah dan dibiarkan ada disekitar kandang dan terdapat sebagian anggota kelompok yang mengalami kesulitan dalam membeli bahan bakar LPG karena dirasa cukup mahal. Metode yang digunakan dalam kegiatan pengabdian kepada masyarakat terdiri atas kegiatan penyuluhan, demonstrasi/praktik dan pendampingan. Hasil kegiatan pengabdian kepada masyarakat yang telah dilakukan menunjukkan adanya penerapan teknologi dalam pengolahan atau pemanfaatan kotoran ternak menjadi bahan yang berguna bahkan memiliki nilai ekonomi akan mendukung terciptanya sistem peternakan yang ramah lingkungan atau sistem peternakan tanpa limbah (zerro waste), selain itu juga akan dapat meningkatkan kesejahteraan peternak melalui minimalisasi cost pembelian bahan bakar.

Kata Kunci: Kotoran ternak, energi alternatif, Amonia, biogas dan efek rumah kaca

*Penulis Korespondensi : Nurkholis

http://comdev.pubmedia.id | Indonesian Journal Publisher | https://idpublishing.org 


\section{PENDAHULUAN}

Kotoran ternak termasuk dalam kategori limbah peternakan, dimana limbah peternakan adalah semua buangan dari usaha peternakan yang dapat berupa padatan (feses), cair (urin), dan gas $\left(\mathrm{H}_{2} \mathrm{~S}, \mathrm{NH}_{3}, \mathrm{CO}_{2}\right.$ dan $\left.\mathrm{CH}_{4}\right)$. Limbah peternakan yang tidak terolah akan dapat menjadi sumber polutan bagi pencemaran air, udara, dan tanah. Limbah peternakan bertanggungjawab dalam kerusakan lingkungan berupa pemanasan global. Pemanasan global terjadi akibat adanya kerusakan pada lapisan ozon. Kerusakan lapisan ozon disebabkan adanya gas metan $\left(\mathrm{CH}_{4}\right)$ yang dihasilkan oleh feses dan urin. Emisi gas metan yang dihasilkan dari limbah peternakan mencapai 20 - 35\% dari total emisi yang dilepaskan ke atmosfir (Ritonga and Masrukhi, 2017).

Peningkatan jumlah populasi ternak yang tidak didukung dengan kebijakan terhadap pengolahan limbah ternak akan dapat menimbulkan permasalahan baru terhadap perkembangan usaha peternakan selanjutnya. Terdapat banyak kejadian dimana usaha peternakan ditutup paksa dikarenakan banyak penolakan dari masyarakat sekitar lokasi peternakan akibat adanya pencemaran, yang dihasilkan dari limbah ternak. Sehingga, dalam mendukung keberlanjutan usaha peternakan tidak hanya dititikberatkan pada kelangsungan hidup dan produksi ternak, melainkan juga pada penanganan serta pengolahan limbah.

Mitra kelompok dalam kegiatan pengabdian masyarakat ini adalah kelompok ternak sapi potong "Sido Makmur" yang ada di desa Umbulrejo, kecamatan Umbulsari, kabupaten Jember. Hasil analisis situasi didapatkan sebagian besar anggota kelompok adalah peternak yang menjalankan usahanya secara tradisional. Rata-rata jumlah kepemilikan ternak sekitar $2-5$ ekor. Teknik pemberian pakan masih secara cut and carry, artinya tergantung pada ketersediaan pakan berupa hijauan yang ada di alam.

Minimnya pengetahuan pada resiko atau bahayanya limbah ternak yang tidak terolah oleh anggota menjadi penyebab utama tidak termanfaatnya kotoran ternak menjadi bahan yang dapat berguna. Limbah ternak yang tidak diolah akan dapat menjadi sumber pencemaran, baik tanah, udara, dan air. Pencemaran adalah masuknya atau dimasukkannya zat, mahluk hidup, atau komponen lain ke dalam lingkungan, yang menyebabkan berubahnya atau turunnya kualitas lingkungan (Sukmana and Muljatiningrum, 2011)

Sapi potong dewasa mampu menghasilkan kotoran padat sebanyak $23,59 \mathrm{~kg}$ per ekor per hari dan kotoran cair 9,07 $\mathrm{kg}$ per ekor per hari (Setiawan, 2007). Diasumsikan rata-rata jumlah sapi potong yang dipelihara oleh anggota kelompok adalah 4 ekor, maka limbah padat yang dihasilkan per harinya adalah sebesar 94,36 kg/hari, dengan rincian 4 ekor x 23,59 $\mathrm{kg} / \mathrm{hari} / \mathrm{ekor}=94,36 \mathrm{~kg} / \mathrm{hari}$, dan jika dihitung dalam satu tahun akan dihasilkan 34,44 ton kotoran padat. Dari hasil ini tidak bisa dibayangkan apabila terdapat banyak populasi ternak sapi potong dengan kondisi limbah yang tidak terolah terhadap bahayanya pada kualitas lingkungan.

Pemanfaatan limbah ternak sapi potong pada kelompok ternak "Sido Makmur" untuk dijadikan sebagai energi alternatif merupakan langkah tepat dalam mengatasi permasalahan yang dihadapi berupa pencemaran lingkungan, disamping itu juga dapat membatu peternak untuk berhemat dalam pengeluaran pembelian bahan bakar, sehingga secara langsung akan meningkatkan kesejahteraan keluarga.

Kotoran sapi potong merupakan bahan yang baik dalam pembuatan biogas bila dibandingkan dengan limbah ternak yang lain, hal ini dikarenakan kotoran sapi memiliki $\mathrm{C} / \mathrm{N}$ rasio 23 (Ritonga and Masrukhi, 2017), persyaratan ideal C/N rasio dalam pembentukan gas metan adalah 20 - 25 (Sukmana and Muljatiningrum, 2011), Unsur nitrogen digunakan sebagai nutrient serta energi bagi pertumbuhan mikroorganisme. Kecukupan nutrisi bagi mikroorganisme dapat meningkatkan kinerja dari mikroorganisme dalam proses dekomposisi bahan organik (Wahyuni, 2009). $1 \mathrm{~m}^{3}$ biogas setara dengan $0,6-0,8$ liter minyak tanah (Wahyuni, 2009), dimana besaran tersebut dapat dipenuhi dengan kepemilikan 2-4 ekor sapi, besaran tersebut mampu memenuhi kebutuhan energi memasak satu rumah tangga (Said, 2010). Dari ulasan tersebut biogas yang dihasilkan dari pengolahan limbah ternak sapi mampu untuk mensubstitusi/menggantikan energi fosil sebagai bahan bakar rumah tangga.

Biogas cukup potensial untuk dikembangkan dengan beberapa alasan diantaranya adalah 1). Ketersediaan bahan baku berupa kotoran ternak selalu ada/melimpah, apalagi didukung dengan adanya program pemerintah tentang peningkatkan jumlah populasi ternak melalui program SIWAB, 2). Terdapat regulasi dibidang energi misal kenaikan tarif dasar listrik dan kenaikan harga bahan bakar fosil serta gas LPG, ini akan mendorong pengembangan sumber energi alternatif terbarukan.

Pemanfaatan kotoran ternak sebagai sumber energi alternatif atau energi terbarukan secara langsung akan membantu negara dalam mengurangi pemanfaatan energi dari fosil. Hal ini bukan tanpa ada alasan, dimana cadangan minyak bumi yang dimiliki sekitar 3,2 - 3,3 miliar barel, dimana angka tersebut sekitar 0,2 persen dari angka cadangan minyak bumi dunia (Anonymous, 2018). Tingkat konsumsi bahan bakar 
minyak mencapai 1,628 juta barel per hari sedangkan produksinya hanya 786 ribu barel per hari (Anonymous, 2016).

\section{METODE}

Metode yang digunakan dalam kegiatan pengabdian kepada masyarakat terdiri atas kegiatan penyuluhan, demonstrasi/praktik dan pendampingan. Penyuluhan adalah salah satu teknik dalam mentransfer ilmu pengetahuan secara nonformal yang bertujuan untuk mengajak kalayak sasaran untuk merubah pola pikir serta perilaku untuk bisa meningkatkan wawasan dan pengetahuan dalam bidang tertentu yang secara langsung dapat memperbaiki tingkat kesejahteraan keluarga.

Demonstrasi/praktik merupakan tindakan/kegiatan yang berfungsi dalam mempertegas serta memperjelas teori dari materi yang disampaikan pada kegitan penyuluhan. Kegitan demonstrasi dilakukan dengan memberikan contoh berupa praktik pembuatan biogas dengan memanfaatkan kotoran ternak. Dengan adanya demonstrasi diharapkan peserta dalam hal ini adalah anggota kelompok ternak "Sido Makmur" secara hard skill terampil dalam mengolah kotoran ternak untuk dijadikan sumber energi alternatif.

Kegiatan pendampingan pada kelompok ternak "Sido Makmur", dilakukan pada saat seluruh rangkaian kegiatan penyuluhan dan demonstrasi dilaksanakan. Pendampingan bertujuan untuk memastikan kelompok ternak tidak mengalami kesulitan dalam mengaplikasikan teknologi yang telah didesiminaskan oleh tim pelaksana pengabdian.

Secara rinci kegiatan penyuluhan, demonstrasi dan pendampingan dapat dijelaskan sebagai berikut:

1. Agenda Pertama:

a. Penyuluhan tentang teknologi pengolahan kotoran ternak untuk dijadikan biogas.

b. Model kegiatan; penyampaian materi dan diskusi

2. Agenda Kedua

a. Demonstrasi pembuatan biogas dengan bahan dasar limbah ternak sapi potong.

b. Model kegiatan; Praktik melakukan pengisian slurry ke dalam tabung digester, di hari ke 20-25 mempraktikan gas bio yang dihasilkan untuk memasak.

3. Agenda Ketiga

a. Pendampingan pada kelompok, kegiatan ini akan dilakukan secara rutin oleh tim pengabdian kepada masyarakat, hal ini sebagai rasa tanggung jawab yang dimiliki, mengingat tugas dan tanggung jawab staf pengajar adalah menjalankan Tri Dharma Perguruan Tinggi, salah satunya yaitu melakukan kegiatan pengabdian kepada masyarakat.

\section{Proses Pembentukan Biogas}

Pembentukan biogas atau gas bio dilakukan pada kondisi tanpa $\mathrm{O}_{2}$ atau anaerob. Metode ini memberikan keuntungan dalam penguraian bahan organik lebih efektif dibandingkan dengan aerob. Pada kondisi anaerob akan memberikan kondisi yang optimal bagi bakteri metan untuk bekerja. Ada beberapa jenis bakteri metan diantaranya adalah Methanobacterium, Methanobacillus, Methanococcus dan Methanosarcina.

Tahapan pembentukan gas bio, yaitu:

1. Hidrolisis, pada tahap ini bakteri memutuskan rantai panjang karbohidrat kompleks; protein dan lipida menjadi senyawa rantai pendek. Contohnya polisakarida diubah menjadi monosakarida, sedangkan protein diubah menjadi peptide dan asamamino.

2. Asidifikasi (Pengasaman), komponen monomer yang terbentuk pada tahap hidrolisis akan menjadi bahan makanan bagi bakteri pembenetuk asam. Produk akhir dari gula sederhana akan dihasilkan asam laktat, asetat, propionat, format, alkohol, dan sedikit butirat, $\mathrm{CO}_{2}$, hidrogen, dan amoniak. Tahap ini termasuk reaksi eksotermis yang menghasilkan energi.

$\mathrm{C}_{6} \mathrm{H}_{12} \mathrm{O}_{6} \rightarrow 2 \mathrm{C}_{2} \mathrm{H}_{5} \mathrm{OH}+2 \mathrm{CO}_{2}+2$ ATP $(-118 \mathrm{~kJ}$ per mol $)$

3. Metanogenik, pada fase ini asam asetat akan dijadikan sebagai subtrat oleh bakteri pembentuk gas metana untuk dirubah menjadi gas $\mathrm{CH}_{4}$ dan $\mathrm{CO}_{2}$.

Biogas sudah terbentuk pada 4-5 hari setelah biodigester terisi penuh, dan mencapai puncaknya pada hari ke 20-25 hari.

\section{HASIL DAN PEMBAHASAN}

Kegiatan pengabdian kepada masyarakat dilakukan dengan khalayak sasaran kelompok ternak "Sido Makmur" yang beralamat di desa Umbulrejo, kecamatan Umbulsari, kabupaten Jember. Dalam pelaksanaannya menggunakan beberapa metoda pendekatan yaitu supervisi, penyuluhan, dan demonstrasi atau praktik serta pendampingan.

Supervisi lokasi dimaksudkan untuk mendapatkan informasi tentang permasalahan yang dihadapi oleh kelompok ternak sehingga nantinya akan didapatkan keselarasan antara program pengabdian dengan kebutuhan kelompok dalam mengatasi masalah tersebut. 


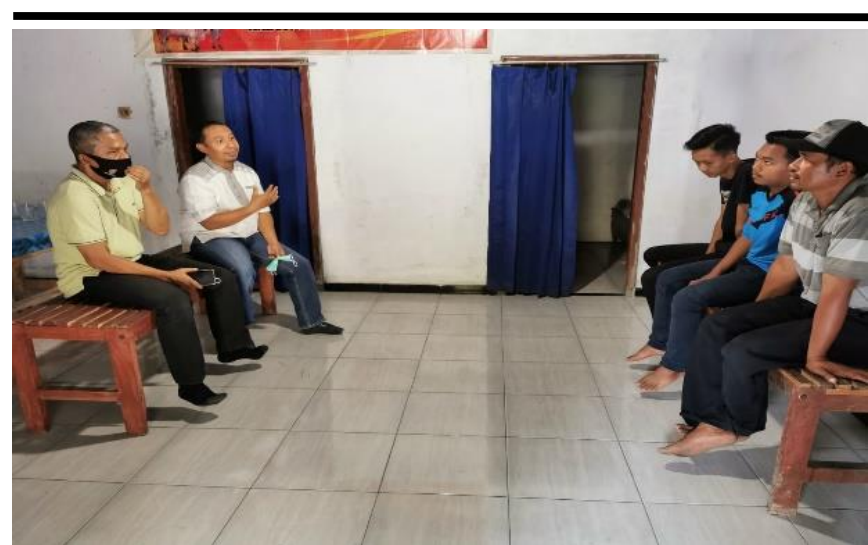

Gambar 1. Kegiatan supervisi lokasi pengabdian

Kegiatan penselarasan program meliputi pembuatan dan penyusunan agenda kegiatan, penjelasan gambaran program kegiatan, tujuan dan manfaat dari kegiatan, serta target yang ingin dicapai dari kegiatan pengabdian. Supervisi dilakukan oleh tim pelaksana kegiatan pengabdian. Pada kegiatan supervisi banyak diperoleh informasi mengenai masalahmasalah yang dihadapi oleh kelompok ternak, informasi tersebut didapat dari hasil diskusi dengan ketua dan beberapa anggota kelompok. Prioritas permasalahan yang segera diatasi adalah pengolahan kotoran ternak yang tidak termanfaatkan. Solusi yang ditawarkan dalam mengatasi permasalahan tersebut dalam pengabdian ini yaitu pengolahan kotoran ternak untuk dijadikan sumber energi alternatif.

Kotoran ternak memiliki potensial besar untuk dijadikan sebagai sumber energi, hal ini didasarkan pada kandungan gas yang dimiliki yaitu gas methan. Selanjutnya energi alternatif dari kotoran ternak disebut sebagai biogas. Biogas hasil dari pengolahan limbah ternak merupakan hasil penerapan teknologi tepat guna, yaitu pemanfaatan instalasi sederhana yang memiliki fungsi menyerupai organ pencernaan (digester).

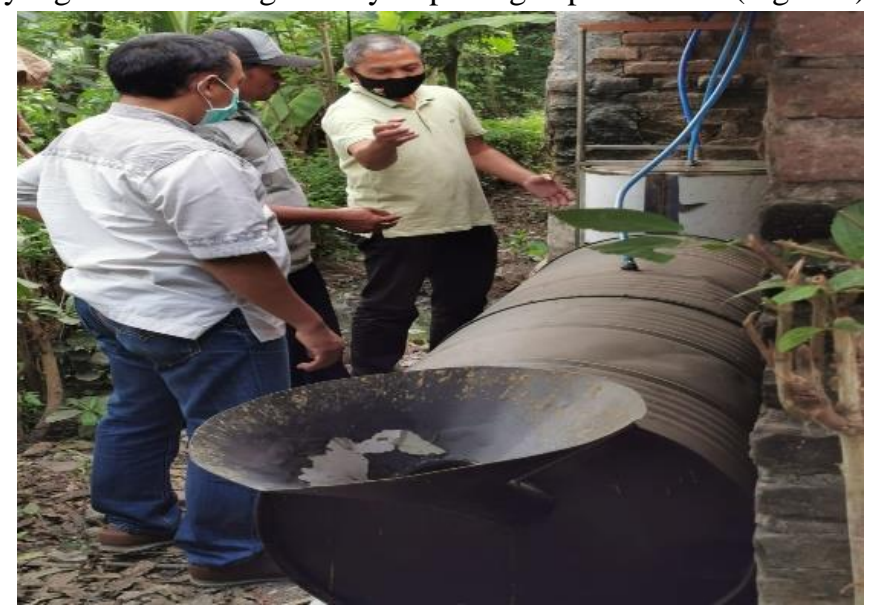

Gambar 2. Pelatihan instalasi biogas
Instalasi biogas dibuat dengan menggunakan bahanbahan yang mudah didapat dan tersedia dipasaran. Mudahnya bahan yang digunakan berimplikasi pada kemudahan pengaplikasian proses pembuatan. Penting untuk diperhatikan bahwa bahan yang digunakan adalah bahan yang tidak mudah berkarat, hal ini dikarenakan beberapa gas yang dihasilkan dari proses fermentasi bersifat korosif.

Dalam kegiatan pengabdian ini, dilakukan pula diseminasi pembuatan instalasi biogas. Bahan yang digunakan adalah logam yang telah dilapisi zat anti karat. Tabung digester dibuat dengan kapasitas 400 liter sedangkan volume tabung penampung gas methan $1 \mathrm{~m}^{3}$. Dengan besarnya volume tersebut mampu mencukupi ketersediaan bahan bakar memasak selama sekitar 2 sampai 3 jam/hari. Digester didesain secara horisontal dengan harapan ketersediaan gas methan akan ada setiap saat dengan kemudahan dalam memasukkan kotoran ternak sebagai bahan baku.

Kegiatan penyuluhan dilakukan dengan metoda tanya jawab atau diskusi, hal ini dimaksudkan untuk lebih banyak memberikan solusi terhadap permasalahan khususnya tentang teknik mengolah kotoran ternak menjadi sumber energi alternatif. Penyuluhan bertujuan merubah sikap dan perilaku peternak untuk bisa lebih berkembang lagi dalam berusaha guna meningkatkan kesejahteraan keluarga. Hasil dari kegiatan penyuluhan ini yaitu anggota kelompok mengerti dan memahami besarnya manfaat dari kotoran ternak untuk dijadikan sebagai bahan yang berguna bagi kehidupan manusia terutama dijadikan sumber energi alternatif.

Praktik atau demonstrasi merupakan metoda yang selanjutnya diterapkan dalam kegiatan pengabdian. Pemilihan metoda ini cukup tepat untuk transfer keterampilan dan pengetahuan khususnya pengoperasinonalan instalasi biogas. Pengoperaisoanalan instalasi biogas cukup mudah dilakukan, praktinya adalah sebagai berikut; bahan baku berupa kotoran ternak dimasukkan kedalam tabung digester melalui lubang inlet, yang sebelumnya kotoran diencerkan terlebih dahulu dengan air (perbandingan 1:1-2) dan dihomogenkan, tabung digester diisi kotoran hingga 2/3 dari volume total, kotoran didiamkan hingga 20-25 hari untuk fermentasi secara sempurna sampai terbentuk gas methan, gas methan yang terbentuk ditampung dalam tabung penampung sebelum digunakan sebagai bahan bakar. 


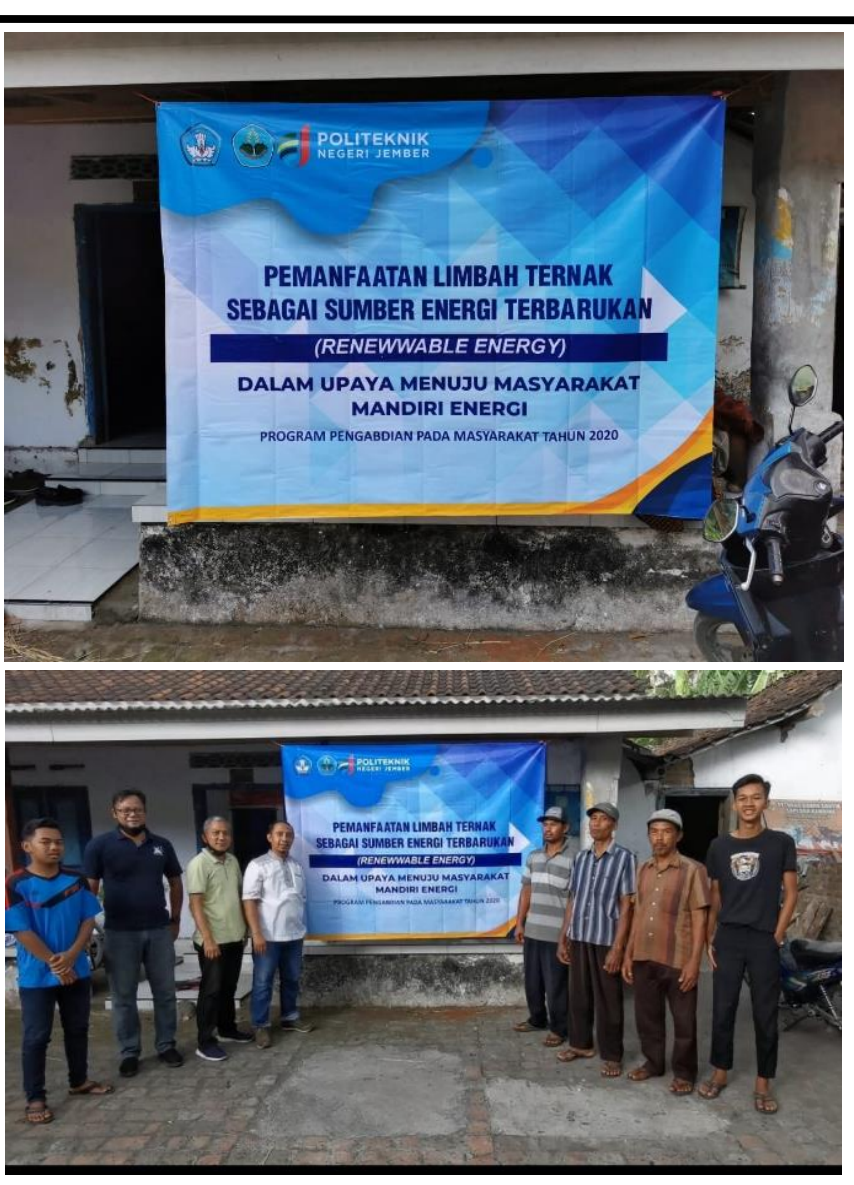

Gambar 3. Pelaksanaan kegiatan pengabdian

Hasil dari kegiatan praktik, peserta dalam hal ini adalah anggota kelompok ternak sapi potong Sido Makmur cukup antusias didalam mengikuti seluruh rangkaian kegiatan. Tahap-tahap yang harus dilakukan dari penyiapan bahan baku hingga pemasukan bahan baku dalam digester serta pengoperasinolan kompor cukup dipahami.

Gas hasil pengolahan kotoran ternak secara langsung dapat dimanfaatkan oleh kelompok ternak sebagai bahan bakar setelah menunggu waktu \pm 22 hari. Termanfaatkannya kotoran ternak menjadi biogas memberikan kontribusi besar bagi mitra untuk dapat miningkatkan kesejahteraan melalui kemandirian dalam ketersediaan energi untuk pemenuhan kehidupan seharihari.

Terdapat empat manfaat yang didapatkan oleh anggota kelompok ternak dari teknologi pengolahan kotoran ternak untuk dimanfaatkan sebagai sumber energi alternati diantaranya menjaga kualitas lingkungan, menghemat biaya pengeluaran untuk pembelian bahan bakar minyak, dan mendapatkan tambahan income dari penjualan slurry (pupuk organik) yang merupakan hasil samping biogas. Disamping itu adanya teknologi dalam pengolahan kotoran ternak menjadi bahan yang berguna bahkan memiliki nilai ekonomi akan mendukung terciptanya sistem peternakan yang ramah lingkungan atau sistem peternakan tanpa limbah (zerro waste).

\section{KESIMPULAN}

Pengetahuan dan teknologi yang didesiminasikan pada kegiatan pengabdian kepada masyarakat mampu menjawab permasalahan yang ada pada kelompok ternak Sido Makmur. Mitra terbantukan dalam pemenuhan kebutuhan energi sebagai bahan bakar.

\section{UCAPAN TERIMAKASIH}

Penulis ingin menyampaikan ucapan terimakasih kepada; (1) Direktur Politeknik Negeri Jember, (2) Ketua P3M Politeknik Negeri Jember, (3) Ketua jurusan Peternakan Politeknik Negeri Jember, (4) Tim Pelaksana Pengabdian Kepada Masyarakat, dan (5) Ketua dan anggota kelompok ternak sapi potong Sido Makmur Umbulrejo - Umbulsari, Jember, atas segala bantuan dan dukungannya sehingga penulis dapat menyelesaikan kegiatan Pengabdian Kepada Masyarakat dari sumber pendanaan PNBP Politeknik Negeri Jember Tahun 2020.

\section{DAFTAR PUSTAKA}

Anonymous (2016) Minyak Bumi Indonesia - Produksi \& Konsumsi Minyak Mentah Indonesia Investments. Available at: https://www.indonesia-

investments.com/id/bisnis/komoditas/minyak-bumi/item267 (Accessed: 12 February 2021).

Anonymous (2018) Cadangan Energi Bikin Negara Kuat - Nasional Tempo.co. Available at: https://nasional.tempo.co/read/1146687/cadangan-energi-bikinnegara-kuat (Accessed: 12 February 2021).

Ritonga, A. M. and Masrukhi, M. (2017) 'Optimasi Kandungan Metana (CH4) Biogas Kotoran Sapi Menggunakan Berbagai Jenis Adsorben', Rona Teknik Pertanian, 10(2), pp. 11-22. doi: 10.17969/rtp.v10i2.8493.

Said, S. (2010) Biogas Untuk Listrik Skala Rumah Tangga. Seri Bioga. Jakarta: Penerbit Indocamp.

Setiawan, A. I. (2007) Memanfaatkan Kotoran Ternak. Cetakan Ke. Jakarta: Penebar Swadaya.

Sukmana, R. W. and Muljatiningrum, A. (2011) Biogas dari Limbah Ternak. Bandung: Nuansa.

Wahyuni, S. (2009) Biogas. Jakarta: Penebar Swadaya. 